\title{
The Convergence of Online Teaching and Problem Based Learning Modules amid the COVID-19 Pandemic
}

\author{
Daniel Bumblauskas ${ }^{1}$ and Nick Vyas ${ }^{2}$ \\ ${ }^{1}$ University of Northern lowa, Cedar Falls, lowa, USA \\ ${ }^{2}$ Center for Global Supply Chain Management, University of Southern California, Los Angeles, \\ California, USA \\ daniel.bumblauskas@uni.edu \\ nikhilvy@marshall.usc.ed
}

\begin{abstract}
There is a convergence unfolding between two formerly unique and separate areas of teaching research methodology: distance education and problem-based learning (PBL) environments. Much has been published on each field independently, however, in the modern-era of online, distance, and hybrid educational programs there is a need for more case and experiential-based learning activities which can effectively measure stated learning objectives. Trends in education have led to the development of various methods to instruct courses and conduct research online. Teaching research methodology and pedagogy have evolved to include video capture, remote conferencing, and other real-time communications techniques allowing faculty and students to collaborate across great distances. Meanwhile, PBL environments have been used extensively in teaching medicine, clinical practice, law, business/management, and many other disciplines to improve student learning. This has been further accelerated during the COVID-19 pandemic through the use of technologies like Zoom, WebEx, GoToMeeting, Google Hangout Meet, etc. and the availability of PBL-ready environments in breakout rooms and asynchronous simulated projects. Student preference data from 2020 are reported as part of this study. One example of this merger between online delivery and PBLs was the development of a PBL statistical process control (PBL-SPC) module. A cross-functional academic team was created across both a college of business and college of education in which a PBL-SPC module was developed based on a real-life situation in which students immerse themselves in a potato chip factory environment. The motivation for the PBL-SPC was that this is a challenging topic to cover which students often find difficult to relate to and/or boring. Three different scenarios were developed and students, as individuals or in teams, must traverse the simulated factory to assess the situation. Learning outcomes are measured by the course instructors and the PBL environment is being used by faculty around the world. Additionally, the PBL-SPC module has now been scaled to other applications such as six-sigma simulated project training during the COVID-19 pandemic. Pedagogical methods should be interactive, stimulate learning, improve the learning outcomes / critical thinking, and enhance student experience. This paper proposes that merging the effective and tech-friendly pedagogical methods of PBLSPC, with the right modalities and model of online delivery, can help achieve these aforesaid goals. Even more, it can deliver a great opportunity to educators and institutions worldwide for advancing the reach of education.
\end{abstract}

Keywords: Online Education, Distance Education, Hybrid Educational Models, Problem Based Learning Modules, Teaching, Pedagogy, COVID-19 Pandemic

\section{Introduction}

The COVID-19 pandemic has dramatically spurred the adoption of online learning. This is a positive trend for educators and institutions worldwide, as it will help them move closer to achieving two vital aims: make education a public good and make quality education accessible for all. However, the spread of e-learning on its own cannot help one achieve the desired objectives. It needs to be accompanied by teaching methods that have the dual capability of improving learning outcomes and a seamless integration with current and emerging digital platforms and technologies.

Students' learning outcomes are closely related to their perceived learning experience (Prosser and Trigwell 1999), therefore it is important that the convergence of the pedagogical methods and digital technologies should be such that it enhances student experience. Secondly, a seamless technological integration is only possible when the teaching method is compatible with different modes and methods of online content consumption such as synchronous and asynchronous delivery formats, and peer-to-peer collaboration. Such a convergence will deliver an incredible opportunity for learners and institutions alike.

Historically, Higher Education Institutions (HEIs) have served as grounds for development of various mediums and methods of instructions and research, that lend themselves to wider dissemination through Information and Communications Technologies (ICT). The broader framework of Higher Education Excellence System, HEES (Vyas, 2019), discussed how HEI is on inflection points and pedagogical innovation along with the teaching 
modality which must be adopted to improve learning outcomes. Major HEls in the United States created extension and distance education programs in the late nineteenth and early twentieth centuries to address the growing need to educate students remotely (Nasseh, 1997). Universities around the world have developed programs aimed at serving domestic and global educational markets. Some of these universities have been leaders in online education and created best-in-class programs. Many universities have extension and outreach departments which serve the local community and states in which they are based.

In the United States, the University of Phoenix is the largest private distance education provider and university in the United States (University of Phoenix, 2009; Altbach and Knight, 2007). There has been much written about Southern New Hampshire University, Kaplan University, Purdue Global, Arizona State University and others that have embraced new models for online learning.

Engineering and business distance education programs have offered an organic growth opportunity for online education. For example, in 1998 Stanford University's Stanford Center for Professional Development announced the first entirely online degree program in electrical engineering (Salisburg, 1998). In addition to entirely online degree programs, hybrid programs which include both on-campus and off-campus work remain popular. The communication mediums available have historically included traditional classroom instruction, correspondence via mail, radio, television, VHS cassette tape, CD-ROM, DVD, the Internet (e.g., streaming video and media), and most recently online meetings (e.g., Zoom, WebEx, GoToMeeting, Google Hangout Meet, etc.). There is also much to be said about synchronous and asynchronous delivery (Miller and Webster, 1997; Davidson-Shivers et al., 2001).

The years following the 2008 financial crisis saw a surge in the growth of e-learning. The primary drivers for this growth have been the ballooning cost of education, globalization, and the advent of disruptive technologies like big data analytics, artificial intelligence, and the Internet of Things (Kortuem et al., 2013). The COVID-19 pandemic in 2019-2020 acted as a super-catalyst for e-learning's growth, seen in the exponential increase in the usage of remote-conferencing software such as Zoom.

\subsection{PBL for improved outcomes}

One major learning that many universities and their faculty can use to further advance their online education offerings is the use of problem-based learning (PBL) models. In PBL, students use "triggers" - in the form of images, media clips, or a simulated environment - from the problem case or scenario to define their own learning objectives (Wood, 2003). PBL uses appropriate problems to increase knowledge and understanding. This application based and PBL models provide students with an immersive experience. It also shifts pedagogy from conventional test-based education programs offered by most on-campus and online institutions to a method of solving problems that has a real-world application. Moreover, the PBL method can be integrated with - and attuned for - the required university, college, program, and course-level learning objectives and outcomes. PBL is an application-based learning system designed to cultivate discussions and increase retention rates amongst students, with numerous examples from medicine (Razzak, Hasan, and Stephen, 2020), veterinary medicine (Howell et al., 2002), physical therapy (Van Duijn, 2004; Walker and Leary, 2009), business (Bumblauskas, 2017), general contexts (Hung et al., 2008), etc. Further, PBL lends itself to a seamless integration with digital platforms like Zoom, WebEx, GoToMeeting, etc. and their specific features like breakout rooms and asynchronous simulated projects.

This paper presents the findings from the utilization of a PBL module in both in-person and online courses. This article also provides a roadmap for deploying online education programs with PBL modules that can be used both synchronously or asynchronously with modern technologies such as Zoom and the various learning management systems (LMS), such as Blackboard, Canvas, Moodle, D2L, etc.

\section{Literature Review}

Over the past 20 years, improvements in video capturing technologies and delivery methods have created a marketplace for undergraduate and graduate coursework and research, particularly for engineering, medicine, and business education. Research has been conducted on the positive and negative aspects of hybrid and online programs for students (EI Mansour and Mupinga, 2007), where flexibility in the class schedule, instructor availability, and online interactions were cited as positives for both online and hybrid courses while technology hiccups and a sense of unfamiliarity with the online environment were cited as negatives. While initially 
contained to executive and corporate business programs -- with a specific case study on the Harvard Business School Executive Education model (DeLacey and Leonard, 2002) -- it has been shown that new on-campus residency components can enrich the student experience providing the ability for students to complete some coursework and requirements remotely while still providing on-campus work to stay connected to the institution, faculty, and peers. In addressing restrictions due to the COVID-19 pandemic, virtual offerings are being used to replicate the on-campus experience as much as possible. This is being done in conjunction with, or in place of, the face-to-face instruction mode as the latter will continue to remain a challenge until the U.S. returns to normalcy.

There has also been research conducted more specifically related to the typical business school case study method delivered through hybrid modes and formats (Webb et al., 2005) and with respect to perceptions of elearning tools and techniques (Ahmed, 2010). Examples of project types delivered through these formats include senior design, capstone projects, and live client projects. A comprehensive review of live-client project literature has been published (Bumblauskas et al., 2015; Bumblauskas, 2018). Design research has also been explored by Cronje (2020a).

Howell et al. (2003) propose that programs need to accommodate the needs of their 'customers' such as fulltime employees and students who need to fulfill family obligations. This notion of the student being considered a customer is a controversial subject in higher education (Browne et al., 1998; Wallace, 1999). However, as noted in the surveys detailed below in section 3, students exercise their choices as consumers when selecting from a menu of options between face-to-face, synchronous online, and asynchronous on-demand content. This is an example of the type of market pressure that is likely to compel universities to "adapt or die (McCallum, 2001)" as students will increasingly seek out providers that will offer multiple delivery modes. Statistics and trends cited in the Howell et al. (2003) study include the educational background of students, their demographic profiles, the impact and required transition of faculty, the role of technology, and competition in the workplace provide - datasets and insights such as ones presented in a consumer survey report. For example, the authors note that female and adult students constitute a larger share of the college age population -- with the University of Texas-Austin (Wong, 2016) being one of the first major universities to report on this back in 2003 -- overshadowing their male peers across the U.S.

Descoteaux et al. (2009) discuss the importance of on-campus residency in detail, where they show that the incorporation of on-campus residency components, either mandatory or optional, helps build a sense of community involvement with the institution and colleagues. Business schools often utilize residency requirements to bring students together to work on cases or practical examples. The same concept can be applied to engineering education to solve problems or investigate specific scenarios, education students in practicums and student teaching, etc.

The growth in demand for continuing education through executive programs and certificate courses has inherently required vast changes in all educational and training infrastructures for corporations and HEls, with Allen and Seaman (2011) publishing the results of a contemporary online education survey study. Continuing education has been gaining both notoriety and acceptance (Haynie, 2014), suggesting that institutions need to continue to rapidly improve their offerings to stay both financially and qualitatively competitive. The HEls pioneering continuing and distance-education programs will continue to have a first-mover competitive advantage. There have been some studies conducted on the perceived learning outcomes from online education which "may be useful as a pedagogical tool for instructors planning learning ventures or to justify technological expenditures at the administrative level" (Eom et al, 2006, p.229).

Today, terminologies such as blended learning (Cronje, 2020b), hybrid delivery, flipped classrooms, etc. are prevalent in pedagogy and the literature. In terms of the impact of the COVID-19 pandemic and trends in eLearning, at least one comprehensive literature review has been conducted by Valverde-Berrocoso, GarridoArroyo, Burgos-Videla, and Morales-Cevallos (2020). It showed that MOOC (Massive Open Online Course) was the most researched e-learning modality and that the case study was the most frequently used methodology.

\section{Distance Education Methods, Marketing, and Study Findings}

Computer technology and streaming have been among the most influential drivers in the growth of distance education. One staggering statistic illustrates its potential: 50 percent of all Chinese engineering graduate in 
their profession via a distance education program (Capper and Potashnik, 1998). But there are challenges in scaling technologies and not all countries have access to the same technology and communication resources and instructor training (Prasojo et al., 2019). Students entering the job market today are no longer only competing locally; in a global economy, students are competing against their peers across the world. This increase in the global availability of business students and engineers will require leaders to differentiate themselves by continuing their education with non-traditional delivery methods.

Marketing is key to success particularly for this branch of the higher education system: to attract students to such programs, HEI must effectively pitch the benefits and skills gained through the respective training programs to their potential students. When browsing any professional periodical e.g., technical trade journals, magazines, newspapers, readers are bombarded with advertisements from providers of distance education. Social media campaigns contain frequent advertisements for online education providers. No matter who the provider is, the methods today call for frequent communication between students and instructors via discussion-board postings and providing students situational vignettes, motivating them to solve the given problems in each scenario. The University of Phoenix and Upper lowa University are examples of institutions that utilize such an applicationbased learning model. However, students and educators must be aware of the potential hazards created by this system. While discussion postings spell a wonderful approach for bringing course topics into a collaborative environment, they can detract from the actual teaching of course topics. Many online institutions do not have instructors. Instead, they have 'co-workers' or 'facilitators.' Interested students should carefully review these instructors' credentials, as some of the most frequent complaints from online students include their dissatisfaction with the program format, a misunderstanding of what is involved in the program, and a feeling that they are not learning as much as they could have through face-to-face interactions.

The marketing of online education is heavily dependent on student experience and testimonials; therefore, it is imperative that continuing education programs retain the same level of quality and discipline as their traditional on-campus counterparts. In fact, one of the primary concerns of educators is the poorer quality of both the material and instruction of distance and online learning. Capper and Potashnik (1998) note that this can be combated primarily by reputation and accreditation. One commonly used quality management platform for $\mathrm{HEIS}$ is the Quality Matters program (https://www.qualitymatters.org/). A reason for the low quality of online instructional methods and material is institutions' unwavering focus on keeping the costs low and therefore affordable for their potential audience present globally. However, the rules of economies of scale do not directly apply in this case, because of regular innovations and adoption of newer technologies is a key requisite. As the number of students increase, delivery costs are mitigated, but support costs are increased in the way of employing, for example, technical support staff and training of instructors and administrators. The emergence of instructional development or technology teams consisting of course designers, web developers, and educational technologists is becoming more prevalent every day.

How do universities market their programs to prospective students and what should students consider when evaluating potential candidates? Reputation stills appears to reign as the dominant variable in evaluating an individual's educational credentials. According to Russell (2004), surveys indicate that private and public sector analysts - including publications that rank $\mathrm{HEI}$ - stigmatize online degrees, obtained especially from institutions that do not have brick-and-mortar campuses. This stigma may be starting to subside (Haynie, 2014) with employers. But students still heavily weigh this factor to evaluate the quality of programs for potential enrollment. The HEI which is the subject of the article, the University of Southern California, has been an extremely aggressive marketer for their online Global Supply Chain Management programs.

Bourne, Harris and Mayadas (2005) reference the Sloan Consortium's members which offer over 600 online programs and the use of "blended" on-campus and online educational programs; reiterating the supply and demand market which has emerged from online distance education. There is fierce competition between institutions offering programs (suppliers) and students (demand), with the demand chain for any organization being particularly important (Bumblauskas, 2015), and in this case the client or customer is the student. After selecting a program, a student must consider the availability of resources to successfully complete coursework and research activities. As is the case with most academic programs, student learning outcomes are greatly impacted by the effort put into completing the requirements of the program.

The COVID-19 pandemic presented an opportunity to understand the preference of students for different modes and formats of delivery. Two different surveys were conducted using Google Forms. These surveys were deemed 
unofficial course surveys as formal evaluations were suspended due to the COVID-19 pandemic. The surveys were originally conducted for teaching informational purposes only at the University of Northern lowa. The students surveyed ( $n=32$ and $n=45)$ were undergraduates in operations management and six sigma consulting courses. We asked students to pick their preferred mode and time of the day for e-learning. It is noteworthy that, when asked to choose between face-to-face, synchronous, and asynchronous modes, significantly higher number of students preferred a recording of the teaching they could peruse when they wished, that is, through the asynchronous mode. Figure $1 \mathrm{~A}$ and Figure $1 \mathrm{~B}$ show rating preferences for face-to-face (before spring break) vs. online class sessions (after spring break 2020). The scale of the surveys was $1=$ very poor, $2=$ fair, $3=$ satisfactory, 4 = very good, 5 = excellent. Figure 2 shows results of a 'desired class-time' survey (summer 2020). The survey results were indicative of a major shift towards a desire for asynchronous mode of delivery i.e., for educational content to be consumed 'on-demand' much in the way that media and entertainment contents are delivered by Netflix, Amazon Music, and other streaming content service providers.

How would you rate the face-to-face portion of the course (i.e., before spring break for spring

2020)?

32 responses

15

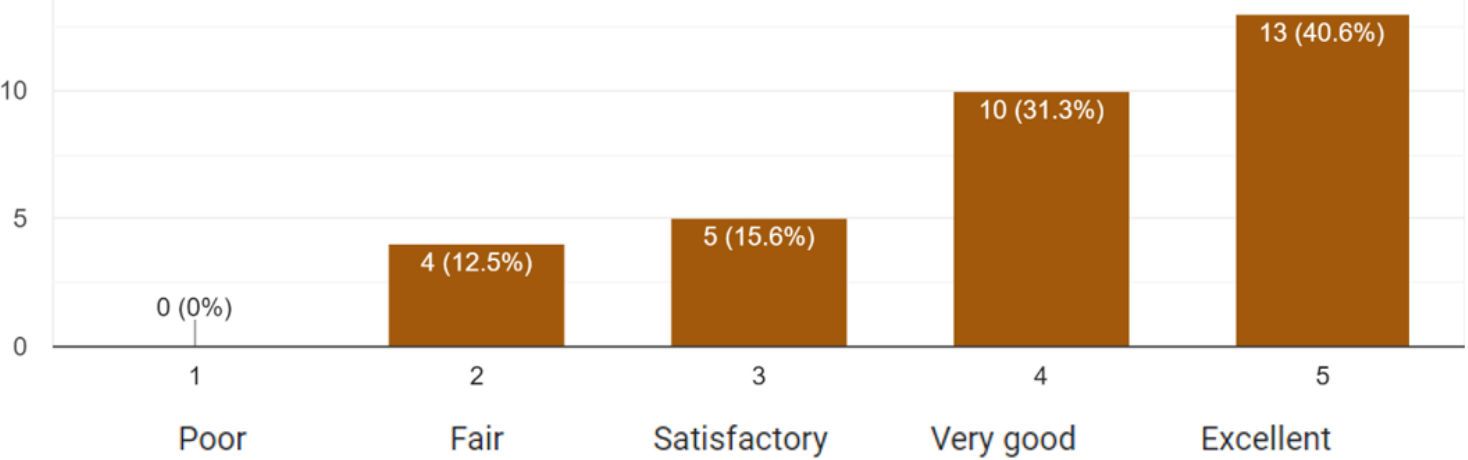

How would you rate the online portion of the course?

32 responses

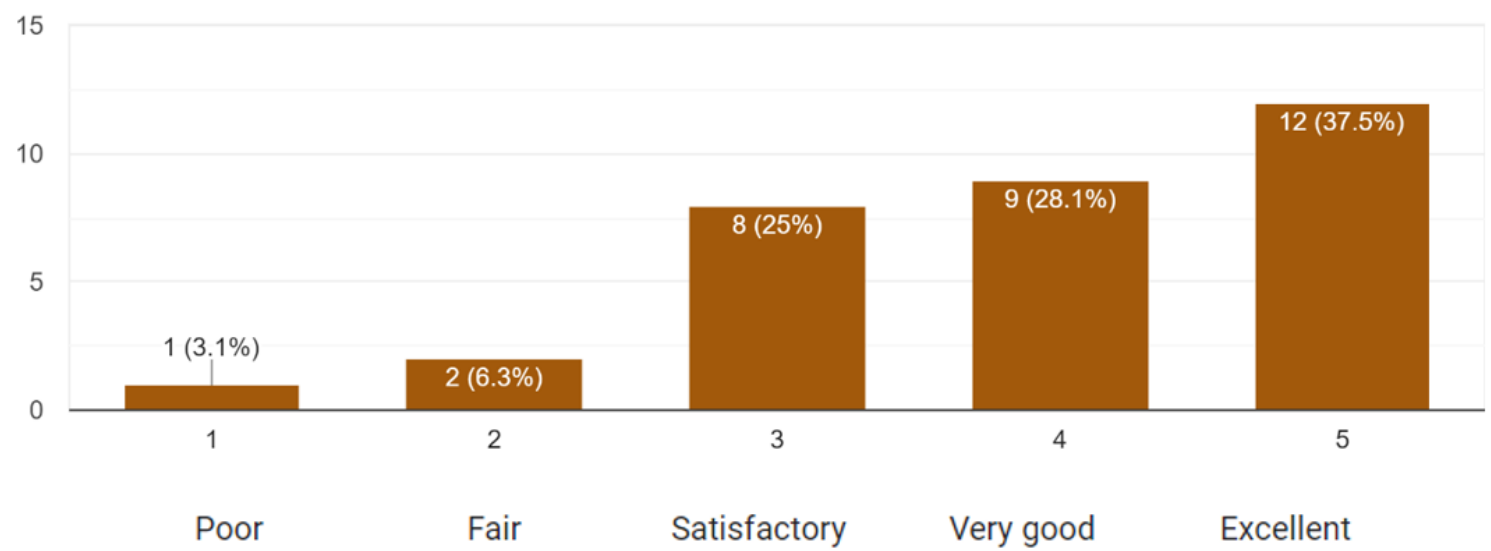

Figures 1A and 1B: Student Ratings for face-to-face vs. online class sessions (spring 2020, unofficial course surveys) 
What time would you prefer to have live class?

45 responses

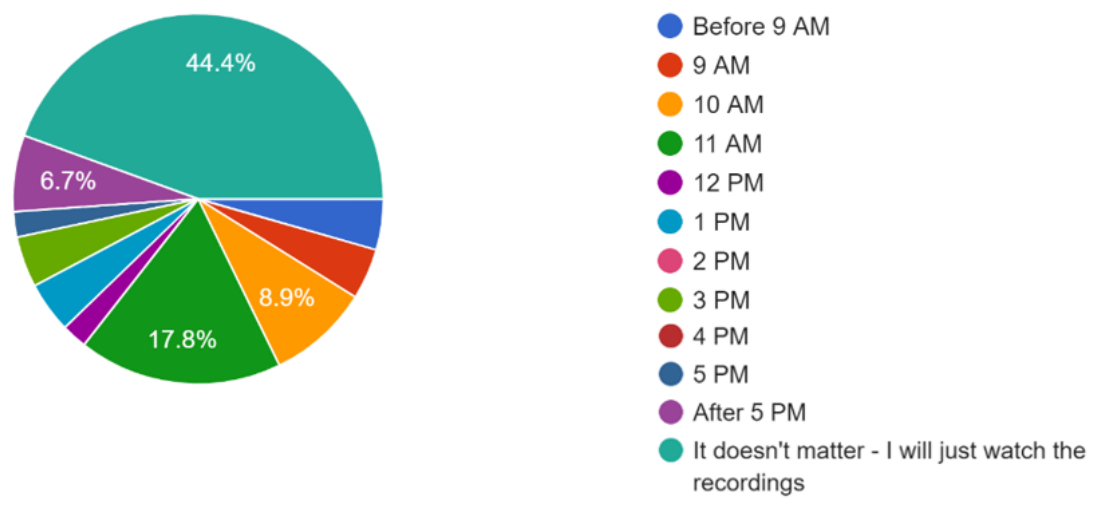

Figure 2: Student Preference for online class sessions (summer 2020, unofficial course survey)

\section{Globalization and Distance Education}

Institutions offering courses, certificates, and degrees via these channels include traditional brick-and-mortar universities, online or virtual universities, professional organizations, and corporations. Remote coursework has enabled the globalization of education as students anywhere in the world can access the best educational resources. The University of Northern lowa's Continuing \& Distance Education unit, lowa State University's Engineering Distance Education, Harvard University's Division of Continuing Education, the University of Phoenix, ABB University, Eaton University, Open University (UK), Khan Academy, etc. are examples of partially remote, entirely remote domestic, entirely remote foreign, and corporate educational solutions. For nondegree seeking students, open-source initiatives such as those of MIT Open Courseware (now MITx, EdX, HarvardX, etc.), Yale University's Open Yale Courses, LinkedIn Learning (formerly Lynda), Coursera, Udacity, etc. are gaining attention from prospective students considering the ever-increasing costs of higher education. All these entities have been quite successful in their target or niche markets.

In Europe, Open University is a British university dedicated to researching and providing distance learning services to the world (The Open University, 2009). Having taught more two million international students to date, since its inception in 1969, Open University has shown that the world is ready to embrace the idea of borderless global education. The European Union, on its part, has a plan in place called e-Europe (European ODL Liaison Committee, 2004), which revolves around the growth and utilization of e-learning programs throughout the union. This policy employs information and communication technologies (ICT's, further defined by Prasojo et al., 2019) to instruct students through various sources such as radio, television, and the Internet.,

As noted above, China educates a substantial percentage of its students via distance education (Capper and Potashnik, 1998). One technique China has utilized to educate the masses is the implementation of The China Education and Research Network, or TV University System (CERNIC). Universities such as the CERNIC, which enroll many students and educate those students utilizing distance-learning curriculum, are known as megauniversities. A formal definition of mega-universities and a list of mega-universities across the globe are available from the United Nations Educational Scientific and Cultural Organization (UNESCO) (United Nations, 2005) and other researchers have studied such universities and the quality of their knowledge delivery and output (Daniel, 1995; Daniel, 1996; Jung, 2005). The largest mega-universities by enrollment are shown in figure 3 (Capper and Potashnik, 1998; University of Phoenix, 2009). It is recommended that countries continue to expand their higher education infrastructure in terms of their distance education offerings. 


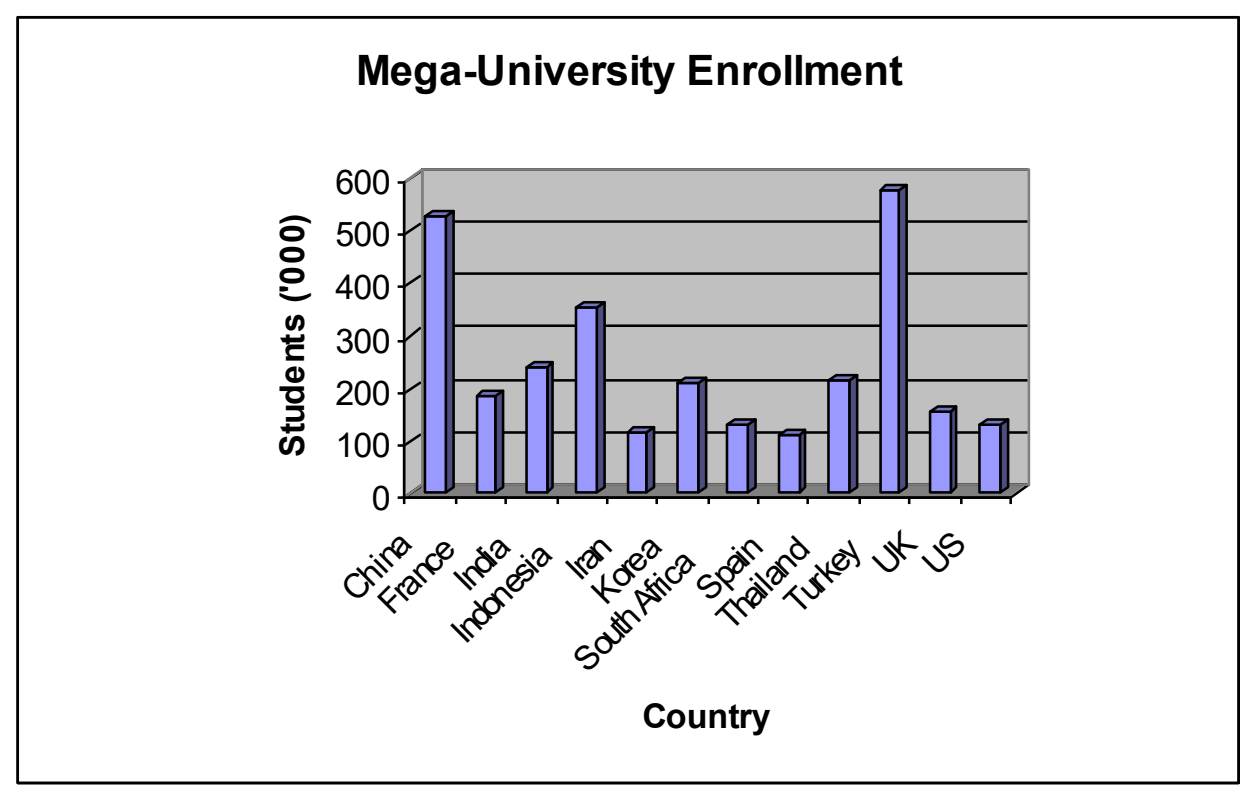

Figure 3: Mega-University Enrollment Statistics by Country as of 2005

\section{Student Experience}

Many distance learning programs are designed for students who may have multiple work/life commitments. The programs, therefore, provide a sufficient degree of flexibility for students to enable them to participate in coursework and research at their convenience. The most common contemporary mode of communication is Internet-enabled online coursework, delivered synchronously or asynchronously. The question of which mode - synchronous or asynchronous - will be preferred more in the future depends on a factor that plays an important role in remote learning and is unique to education: active participation of customers, that is, students. There is an on-going debate regarding the participation of remote students; some believe that online interactions reduce the level participation compared to face-to-face interactions, while others believe that they enable greater participation (e.g., students are less nervous behind a keyboard, some instructors require students to turn on their web cameras to ensure engagement, etc.). Another perceived drawback to online courses is that there are also fewer networking and relationship building opportunities. There is little doubt that face-to-face interactions remain one of the most powerful means of communication as one can pick up on body language, verbal cues (e.g., such as tone, pitch, and inflection), and the physical demeanor of others.

Emerging digital solutions offer features that address some of these gaps. Remote conferencing software such as Zoom, for example, have a reporting feature that allows for webcams to track perceived engagement and some instructors require cameras to be left on. Some of these (reportingg) features mimic traditional benefits of engagement,( observable in face-to-face meetings) to increase participation. Certain courses, for example those involving negotiations with suppliers, benefit from Zoom breakout rooms which realistically mimic today's web-based procurement process. Other examples where greater interaction has been made possible is in the use of social networking sites (e.g., Facebook, LinkedIn, Twitter) and avatar-based communities (e.g., Second Life) for education. It is generally believed that online courses facilitate greater interaction from students that would normally be perceived as introverted during a classroom formatted discussion.

The biggest advantage of online education is the unmatched flexibility of consumption that it offers. Video captures and streamed lectures and coursework allow students the ability to watch course lectures on-demand. Downloads allow students to watch lectures while traveling virtually anywhere (e.g., site offices, automobiles, airplanes, trains, home, etc.). To highlight some examples, lowa State University's Engineering Distance Education Department allows students to download or video-stream lecture content. Harvard University's Extension School allows student to video-stream lecture content. Course learning management software (LMS) suites, such as Blackboard, Canvas, Moodle, etc. provide an interface for the coursework and serve to distribute materials with videos often hosted by Panopto. Conferencing mediums such as traditional teleconferencing services, free web-based teleconferencing services (e.g., Instant Conference), Microsoft Teams and formerly Net Meeting, Sametime Meeting, Skype, Cisco WebEx, Adobe Connect, GoToMeeting, Zoom, etc. provide tools to 
have remote collaboration on projects. Skype remains a useful web-based video-conferencing tool which allows remote participants to join in real-time meetings but is quickly being transformed under Microsoft's acquisition and with MS teams.

The next frontier in online education is enablement of research that could be done remotely and collaboratively. The primary requirement for the enablement of remote research will be access to the institutional library system and laboratories. To conduct an appropriate literature review in any research area, it is critical that the student have access to adequate library resources. Most universities have some form of an e-library available to students (e.g., University e-Library, University Libraries, University Digital Repositories, etc.) and search capabilities (e.g., Google Scholar, etc.).

A lack of virtual laboratory spaces has been one of the roadblocks for online programs in engineering and medicine. To combat this issue, some instructors have begun to develop experiment kits which can be mailed to students in advance for completion of laboratory work (Moltz, 2009). The required scaling of lab-based courses, or lack thereof, has been a major challenge for institutions, during the COVID-19 pandemic.

It is important that a student can work with faculty and staff remotely following the protocols and social etiquettes as one does in a professional environment. Students need to respect the faculty, especially their time, as they would in an on-campus interaction. Likewise, faculty members need to understand the demands faced by remote students studying in an environment which is new for them, as has been for the millions of students worldwide during the last year (2020-21 in the United States). For such hybrid programs to flourish, a hassle-free crossover of traditional processes and protocols is critical. For example, the requirements established by university administrative offices, such as forms, need to be accessible for completion by offcampus students. To prevent the deterrence of prospective students, cumbersome and archaic requirements should be revised or relaxed for ease of completion. However, this must be accomplished without sacrificing any of the program requirements and quality. Any such compromise could irreversibly tarnish the institute's credibility and reputation. An effective way to ensure a successful transition is to make use of resources and recommendations provided by industry advisory boards formed by universities and the faculty of continuing education and learning programs. At many universities, for example, there are on-campus Centers for Excellence in Learning and Teaching which provide resources, services, and recommendations for academic activities and innovations.

\section{Problem Based Learning Modules: A Case Study}

As discussed, there are many types of contemporary online teaching methodologies being deployed across disciplines. One technique that could be deployed to improve the online learning experience is the PBL-SPC (Problem-Based Learning - Statistical Process Control), detailed by Bumblauskas (2017). A team comprised of faculty members and graduate students at the University of Missouri, with representatives from both the colleges of business and college of education, collaborated for the development of a web-based simulation. The simulation allows students to immerse themselves in a Frito-Lay ${ }^{\circledR}$ potato chip factory environment based on Heizer and Render (2013) in their OM (Operations Management) textbook. Little did the team realize at the time how powerful this environment could be during a pandemic; as COVID-19 hit restricting travel and site visitors, this PBL model provided a great substitute to being on-site at a physical location. The original motivation for the PBL focusing on SPC was that students found this to be a challenging topic which was also difficult to relate to and boring.

The PBL-SPC - hosted at the following URL: https://sites.uni.edu/bumblaud -- provides the user with three poorquality scenarios: crushed chips, stale chips, and poor tasting or nasty chips. Students, as individuals or in teams, must traverse the simulated environment to assess the situation. By "speaking," with the fictitious characters created in the simulation, the students get the perspectives of the manufacturing supervisors for each area. In addition, some stations have datasets which can be downloaded as .csv spreadsheets to be further analyzed using statistical process control (SPC) techniques, often in software such as MS Excel. Visitors to the PBL-SPC site can find the project's mission statement, the production line schematic, staff profiles, an operational overview and a production video produced by Heizer and Render (2013) and Munson, Heizer and Render (2017). There are supplemental materials available for the PBL-SPC such as a sample assignment description, scoring rubric, and MS Excel SPC 'solution,' spreadsheet. Individually or in teams, students work on one, two or three of the PBL-SPC scenarios available on the website (crushed chips, stale chips, and nasty taste). The deliverables 
required often include an analysis of the nasty taste case and submission of the following three items: (1) executive summary or an abstract describing the problem and how the students applied the SPC to solve the PBL, (2) provide an MS Excel SPC solution spreadsheet, and (3) provide and present MS PowerPoint slides. Data analytics courses can also consider deliverables that build more sophisticated dashboards to convey metrics to be used for management decision making.

The PBL-SPC model has since been scaled and used as part of a six-sigma yellow belt program for university and industry students during the COVID-19 pandemic. The PBL environment provides for a rich simulated landscape for students to explore like a real facility or job site. There are other models of creating learning environments such as the Texas A\&M's Second Life campus (Lastovica, 2012) and gamification (López Carrillo et al., 2019). The runway for this activity and the richness of the environment has proven more significant than any of the original design team could have imagined. While this is just one-use case, PBL can be scaled for all disciplines including those mentioned above (e.g., medicine, veterinary medicine, the sciences, etc.).

\section{Conclusion and Future Work}

This paper provides historical context, a roadmap, and a case for a PBL environment that should be considered by faculty and administrators focused on online, distance, hybrid, and blended education programs. The historical context of online and distance education programs in engineering, business, and executive delivery modes has been provided. Recommendations for ways to improve engagement such as via application based and PBL methods, face-to-face meetings and web-based substitute technologies for faculty-student engagement have been discussed. The development and growth of programs by EdX, HarvardX, massively open online courses (MOOCs), etc. create opportunities for data analytics not yet seen for online education providers. A snapshot of the type of student feedback that can mold online programs is provided (i.e., delivery mode and instructional time of day). However, online education, delivery modes, and activities also create challenges such as preventing cheating (Northcutt et al., 2016). Respondus Lockdown Browser and Respondus [Camera] Monitor are two examples of technologies in this space that are currently being deployed. More research in this area will allow for a better user (student) experience and optimization of delivery methods in the best system for the student, faculty, and administration. One specific item to be considered moving forward is the collection of additional student evaluations to gather feedback on the PBL-SPC activity. This lends itself towards the possible used of mixed methods (Azorin and Cameron, 2010) pedagogical research, linking online distance education component and the PBL-SPC.

Further, being a prominent global hub of the two important drivers that make this trend - education and technology - the U.S. can play a pivotal role in the spread of quality education to millions at home and abroad, much in the way it has helped expand the scope and reach of media and entertainment. At home this could also help address an issue that has been plaguing the U.S. education system for a long time - the escalating cost of higher education. The concept of lecturing for hours today, where attention spans are continuing to shrink, needs to be reinvented. Post-COVID world will demand that learning modality should be changed and adapted in different ways.

\section{Acknowledgements}

Thanks to former lowa State University graduate student researchers Tom Bruton, Josh Colyer, Kendall DeJonge, and James Loghry circa 2005 that laid the early groundwork for this research project.

Portions of this original manuscript were presented at the 2009 ASEE Midwest Regional Conference (Bumblauskas, 2009) and a copyright release was granted by ASEE. The manuscript has been revised significantly since that time.

\section{References}

Ahmed, H. M. S., 2010. Hybrid e-learning acceptance model: learner perceptions. Decision Sciences Journal of Innovative Education, 8(2), pp. 313-346.

Allen, I. E., and Seaman, J., 2011. Going the distance: online education in the United States, 2011. Newburyport, MA: Sloan Consortium. Available at: http://files.eric.ed.gov/fulltext/ED529948.pdf [Accessed February 25, 2021].

Altbach, P. G., and Knight, J., 2007. The internationalization of higher education: motivations and realities. Journal of Studies in International Education, 11(3-4), pp. 290-305.

Azorín, J. M., and Cameron, R. 2010. The application of mixed methods in organisational research: A literature review. Electronic Journal of Business Research Methods, 8(2), pp. 95-105. 
Bourne, J. Harris, D. and Mayadas, F., 2005. Online engineering education: learning anywhere, anytime. Journal of Engineering Education. January 2005, pp. $131-146$.

Browne, B. A., Kaldenberg, D. O., Browne, W. G., and Brown, D. J., 1998. Student as customer: factors affecting satisfaction and assessments of institutional quality. Journal of Marketing for Higher Education, 8(3), pp. 1-14.

Bumblauskas, D., 2009., Online distance education: hybrid coursework and research methods. 2009 ASEE Midwest Conference. Lincoln, NE: American Society for Engineering Education. Available at: https://www.researchgate.net/profile/DanielBumblauskas/publication/237271799 Online Distance Education Hybrid Coursework Research Methods/links/58 11664108aee15d491507d4/Online-Distance-Education-Hybrid-Coursework-Research-Methods.pdf Accessed April 4, 2021]

Bumblauskas, D., Rosol, S., and Bumblauskas, P., 2015. Managing multiple consulting projects: a multi-level application of the demand-based approach. DSI Conference. Seattle, Washington: Decision Sciences Institute. Available at: https://decisionsciences.org/wp-content/uploads/2017/11/p1041687.pdf [Accessed February 25, 2021].

Bumblauskas, D., 2017. Guest post: Problem-Based Learning (PBL) for SPC. Jay [Heizer], Barry [Render] and Chuck's [Munson's] OM Blog: A Blog for Operations Management Educators. Available at: https://heizerrenderom.wordpress.com/2017/02/15/guest-post-problem-based-learning-for-spc/ [Accessed February 25, 2021].

Bumblauskas, D., Rosol, S., and Bumblauskas, P., 2018. Managing multiple projects: applying a demand-based approach. International Journal of Management Education, 16(1), pp. 52-62.

Capper, J and Potashnik, M., 1998. Distance education: growth and diversity. World Bank Finance \& Development. Available at: http://www.worldbank.org/fandd/english/0398/articles/0110398.htm [Accessed July 14, 2009].

Cronje, J. C., 2020a. Designing questions for research design and design research in e-Learning. Electronic Journal of eLearning, 18(1), pp. 13-24. Available: https://files.eric.ed.gov/fulltext/EJ1245125.pdf [Accessed September 22, 2020].

Cronje, J. C., 2020b. Towards a new definition of blended learning. Electronic Journal of e-Learning, 18(2), pp. 114-121. Available at: https://files.eric.ed.gov/fulltext/EJ1250468.pdf [Accessed September 22, 2020].

Daniel, J. S., 1995. The mega-universities and the knowledge media: implications of new technologies for large distance teaching universities (Doctoral dissertation, Concordia University).

Daniel, J. S., 1996. Mega-universities and knowledge media: technology strategies for higher education. London/Oxford, UK: Psychology Press.

Davidson-Shivers, G. V., Muilenburg, L. Y., and Tanner, E. J., 2001. How do students participate in synchronous and asynchronous online discussions? Journal of Educational Computing Research, 25(4), pp. 351-366.

DeLacey, B. J., and Leonard, D. A., 2002. Case study on technology and distance in education at the Harvard Business School. Educational Technology \& Society, 5(2), pp. 13-28.

Descoteaux, T., Muckerman, D., Sabol, S., 2009. The importance of an on-campus residency experience in distance education programs. ASEE Annual Conference \& Exposition Proceedings, Austin, TX: American Society for Engineering Education.

El Mansour, B., and Mupinga, D. M., 2007. Students' positive and negative experiences in hybrid and online classes. College Student Journal, 41(1), pp. 242.

Eom, S. B., Wen, H. J., and Ashill, N., 2006. The determinants of students' perceived learning outcomes and satisfaction in university online education: an empirical investigation. Decision Sciences Journal of Innovative Education, 4(2), pp. 215-235.

European ODL Liaison Committee, 2004. Distance learning and e-Learning in European policy and practice: the vision and the reality. European Distance and E-Learning Network. Available at: http://www.odlliaison.org/pages.php?PN=policy-paper 2004 [Accessed July 14, 2009].

Goodson, C., Miertschin, S., Stewart, B., Norwood, M., Faulkenberry, L., 2009. Online distance education and student learning: do they measure up? ASEE Annual \& Exposition Conference Proceedings, Austin, TX: American Society for Engineering Education.

Haynie, D., 2014. How employers view your online bachelor's degree. US News \& World Report Education. March 4, 2014. Available at: http://www.usnews.com/education/online-education/articles/2014/02/28/what-employers-reallythink-about-your-online-bachelors-degree [accessed July 15, 2016].

Heizer, R., and Barry, R., 2013. Operation management, sustainability and supply chain management (Vol. 11). UK: Pearson.

Heizer, J., Render, B. and Munson, C., 2017. Principles of operations management: sustainability and supply chain management (Global edition). UK: Pearson.

Howell, N. E., Lane, I. F., Brace, J. J., and Shull, R. M., 2002. Integration of problem-based learning in a veterinary medical curriculum: first-year experiences with application-based learning exercises at the University of Tennessee College of Veterinary Medicine. Journal of Veterinary Medical Education, 29(3), pp. 169-175.

Howell, S., Williams, P., and Lindsay. N., 2003. Thirty-two trends affecting distance education: an informed foundation for strategic planning. University of West Georgia Online Journal of Distance Learning Administration. 6(3). Available at: http://www.westga.edu/ distance/ojdla/fall63/howell63.html [Accessed July 15, 2016].

Hung, W., Jonassen, D. H., and Liu, R., 2008. Problem-based learning. Handbook of research on educational communications and technology, 3, pp. 485-506. 
Jung, I., 2005. Quality assurance survey of mega universities. Perspectives on distance education: lifelong learning and distance higher education, pp. 79-98.

Karkar, A. J., Fatlawi, H. K., and Al-Jobouri, A. A., 2020. Highlighting e-Learning adoption challenges using data analysis techniques: University of Kufa as a case study. Electronic Journal of e-Learning, 18(2), pp. 136-149. Available at: https://files.eric.ed.gov/fulltext/EJ1250429.pdf [Accessed September 22, 2020].

Kibuku, R. N., Ochieng, D. O., and Wausi, A. N., 2020. e-Learning challenges faced by universities in Kenya: a literature review. Electronic Journal of e-Learning, 18(2), pp. 150-161. Available at:

https://files.eric.ed.gov/fulltext/EJ1250436.pdf. [Accessed September 22, 2020].

King, A., 1993. From sage on the stage to guide on the side. College teaching, 41(1), pp. 30-35.

Kortuem, G., Bandara, A. K., Smith, N., Richards, M., and Petre, M., 2013. Educating the Internet-of-Things generation. Computer, 46(2), pp. 53-61.

Lastovica, M., 2012. Teaching With 'Second Life'. Texas A\&M Today. Available at: https://today.tamu.edu/2012/09/27/texas-am-and-university-of-arkansas-collaborate-along-with-texas-tech-inteaching-students-with-second-life/ [Accessed September 22, 2020].

López Carrillo, D., Calonge García, A., Rodríguez Laguna, T., Ros Magán, G., and Lebrón Moreno, J. A., 2019. Using gamification in a teaching innovation project at the University of Alcalá: a new approach to experimental science practices. Electronic Journal of e-Learning, 17(2), pp. 93-106. Available at: https://files.eric.ed.gov/fulltext/EJ1220168.pdf [Accessed September 22, 2020].

Mazzolini, M., and Maddison, S., 2003. Sage, guide, or ghost? The effect of instructor intervention on student participation in online discussion forums. Computers \& Education, 40(3), pp. 237-253.

McCallum, J. S., 2001. Adapt or die. Ivey Business Journal, 66(2), pp. 72-74.

Miller, W. W., and Webster, J. K., 1997. A comparison of interaction needs and performance of distance learners in synchronous and asynchronous classes. U.S. Department of Education: Educational Resources Information Center.

Moltz, D., 2009. Home Dissection Kits and More. Inside Higher Ed. June 5, 2009. Available at: http://www.insidehighered.com/news/2009/06/05/science [Accessed July 15, 2016].

Morse, R., 2009. University of Southern California and the engineering rankings. U.S. News and World Report. Available at: http://www.usnews.com/blogs/college-rankings-blog/2009/06/11/university-of-southern-california-and-theengineering-rankings.html [Accessed July 15, 2016].

Nasseh, B., 1997. A brief history of distance education. Adult Education in the News: Ball State University, 1(1), pp.1-14.

Northcutt, C. G., Ho, A. D., and Chuang, I. L., 2016. Detecting and preventing "multiple-account" cheating in massive open online courses. Computers \& Education, 100, pp. 71-80.

Potter, N., 2011. Netflix CEO apologizes for price increase, announces qwikster service to mail DVDs. ABC News. Available at: http://abcnews.go.com/blogs/technology/2011/09/netflix-ceo-apologizes-for-price-increase-announces-qwiksterto-mail-dvds/ [Last accessed July 15, 2016].

Prasojo, L. D., Habibi, A., Yaakob, M. F. M., Mukminin, A., Haswindy, S., and Sofwan, M., 2019. An explanatory sequential study on Indonesian principals' perceptions on ICT integration barriers. Electronic Journal of e-Learning, 17(1), pp. 110. Available at: https://files.eric.ed.gov/fulltext/EJ1213053.pdf [Accessed September 22, 2020].

Prosser M, Trigwell K., 1999. Understanding learning and teaching: the experience in higher education. Buckingham, UK: McGraw-Hill Education.

Razzak, R. A., Hasan, Z., and Stephen, A., 2020. Medical student perceptions of integration of a customized cloud based learning operating system into Problem Based Learning (PBL) tutorials. Electronic Journal of e-Learning, 18(1), pp. 2539. Available at: https://files.eric.ed.gov/fulltext/EJ1245291.pdf [Accessed September 22, 2020].

Russell, J., 2004. Online universities fight stigma their degrees aren't worth much. The Boston Globe. Available at: http://www.boston.com/news/education/higher/articles/2004/11/07/online universities fight stigma their degre es arent worth as much/ [Accessed July 15, 2016].

Rutz, E., 2000. Use of distance learning for continuing education of engineers: results of an educational needs assessment. Journal of Engineering Education. July 2000, pp. 261-264.

Salisburg, D.F., 1998. Stanford offering its first complete online degree program. Stanford University Press Release. Stanford, CA. 1998. Available at: http://news.stanford.edu/pr/98/980724webdegree.html [Accessed July 15, 2016].

The Open University, 2009. The Open University mission statement. The Open University. Available at: http://www.open.ac.uk/about/ou/p2.shtml or http://www.open.ac.uk/about/main/mission [Accessed July 15, 2016].

United Nations, 2005. United Nations Educational Scientific and Cultural Organization (UNESCO) mega universities. UNESCO. Available at: http://portal.unesco.org/education/en/ev.phpURL ID=42857\&URL DO=DO TOPIC\&URL SECTION=201.htmI [Accessed July 15, 2016].

University of Phoenix, 2009. Media relations. University of Phoenix, Inc. Available at: http://www.phoenix.edu/about us/media relations.html [Accessed July 14, 2009].

Valverde-Berrocoso, J., Garrido-Arroyo, M. D. C., Burgos-Videla, C., and Morales-Cevallos, M. B., 2020. Trends in educational research about e-Learning: a systematic literature review (2009-2018). Sustainability, 12(12), 5153, pp. 1-23. Available at: https://www.mdpi.com/2071-1050/12/12/5153/pdf [Accessed September 22, 2020].

Van Duijn, A. J., 2004. Clinical performance of physical therapy students in problem-based, mixed-model, and traditional curriculum. Unpublished doctoral dissertation, University of Central Florida.

Vyas, N., 2019. Use of blended quantitative/ qualitative TQM model in Higher Education Institutes (HEI). Los Angeles: University of Southern California. 
Walker, A., and Leary, H., 2009. A problem-based learning (PBL) meta-analysis: differences across problem types, implementation types, disciplines, and assessment levels. Interdisciplinary Journal of Problem-based Learning, 3(1), pp. 6-28.

Wallace, J. B., 1999. The case for student as customer. Quality progress, 32(2), pp. 47.

Webb, H. W., Gill, G., and Poe, G., 2005. Teaching with the case method online: pure versus hybrid approaches. Decision Sciences Journal of Innovative Education, 3(2), pp. 223-250.

Wong, C. (2016). For 12 years running, more women than men attend UT. The Daily Texan. April 11, 2016. Available at: http://www.dailytexanonline.com/2016/04/11/for-12-years-running-more-women-than-men-attend-ut [Accessed July 15, 2016].

Wood, D.F., 2003. Problem based learning. Bmj, 326(7384), pp. 328-330. 